\title{
Urban Renewal: A Field in the Making for Applied Social Sciences?
}

\author{
Maya Leclercq \\ Sociotopie
}

Professional socio-anthropology can be applied to private but also to public sector, for example in the context of the evaluation of public policies. In this article, we will focus on urban renewal projects, which have been particularly invested by sociologists and anthropologists over the past twenty years. We will explore the demand for urban sociology through the emergence of the notion of "usage expertise". Indeed, it is particularly in this field that the skills of urban socio-anthropology come into play.

Keywords: ANRU, urban sociology, concertation, applied research, public policy

\section{FROM RESEARCHER TO PRACTITIONER IN THE FIELD OF URBAN SOCIOLOGY}

After finishing a traditional university course for the doctorate degree in socio-anthropology completed in 2010, I turned to action research or applied research ${ }^{1}$, defining myself as an independent sociologist or practicing sociologist. I became a practitioner due to a conviction - the conviction of the advantages that lay in associating the humanities and social sciences with complex, multi-stakeholder projects and at the heart of major current issues (environment, land management... or urban renewal). I also use my researcher's perspective to examine the conditions of this practice. For several years, I have been exploring the "social demand" for my discipline in different themes and sectors, particularly on development and industrial projects in West and Southern Africa, and since 2015 on urban projects, particularly in the Hauts-de-France Region.

In particular, I wonder about the difficulty of the Humanities and social sciences, and more precisely of sociology and anthropology. Although the 2000s are sometimes considered as a turning point in the emergence of practical sociology (Piriou, Olivier 2008, quoted by Akermann, 2018), and increasing demand of presence of a "sociologist" in constitution of teams in order to respond to public markets, the use of the Humanities and social sciences is still far from being established, to the point where some authors define the demand for sociology as "increasing, but not very great" (Granier,Ould-Ferhat, and Thobois 2018: 6).

Concerning the field of urban planning, over the past twenty years or so, we have seen a trend of strengthening of interactions between sociologists and urban public policy actors, with the emergence of hybrid items such as CIFRE $^{2} \mathrm{PhDs}$, but also the emergence of hybrid actors, such as sociologistsurbanists (working within urban planning agencies, certain territorial authorities and sometimes architectural agencies) or the growing demand for sociological and anthropological expertise in the context of public tenders. This request is now more precise, even autonomous with regard to urban studies, traditionally carried out by architectural and urban planning agencies. More specifically, urban studies generally include a "social component", treated as a subsection of the urban study and therefore 
generally handled directly by the architectural and urban planning agencies mandated by the project. In recent years, the specifications for sociological studies in urban projects have become more developed and increasingly independent of urban studies. The separation of urban and social aspects has become a feature of $\mathrm{ANRU}^{3}$. This observation of an increase in the demand for sociology in the context of public procurement for urban projects is shared by Gregori Akermann: "The formal demand for sociology that is expressed through the Boamp ${ }^{4}$ exists, but it appears to be extremely limited and largely embedded in multidisciplinary approaches. Nevertheless, the large proportion of requests concerning the field of planning and urban development seems to go in the direction of the emergence of a market for sociologists specialising in urban issues, which could be explained by a long standing existence of urban sociology in connection with public procurement (Lassave 1997)"(Akermann 2018, 34).

I have been carrying out urban sociology studies since 2015, particularly in the context of public procurement in the Hauts-de-France region, and my professional practice is therefore at the heart of this demand. In this article, I propose several angles of approach to understand the emergence of the demand for applied urban sociology. I will start with a bibliographical analysis of different currents of "involved" or "applied" urban sociology, before focusing on a subject, that of the participation (or even co-construction) of inhabitants in urban projects, of which the sociologist has become a kind of "mediator".

This reflection is based on the interviews conducted in 2017 with public policy actors and researchers on the theme of the demand for urban sociology, on a bibliographic research project and on reflections and lessons learned from my experience in various urban projects carried out in recent years in Hauts-de-France.

\section{SOCIOLOGICAL STUDIES AND URBAN RENEWAL: ANCIENT HISTORY?}

The exercise of summarising half a century of urban sociology has already been carried out by many authors $^{5}$ and this is by no means my ambition for this article. Rather, I intend to focus on the main stages of the historical construction of urban sociology and public demand (requiring by definition an applied approach), which are carried out at different scales, in order to contextualize and provide analytical keys to understand the progressive historical construction of the new (or renewed) role of sociologists in the field of urban planning.

Urban sociology has always been both a theoretical and an empirical field, focusing on the city and the conditions of its production as a way to reveal social relationships. Like many disciplines, it does not consist of cumulative work but is distinguished by the discontinuity and heterogeneity of the work that it is composed of (Topalov 2005; Probetich 2010; quoted by Grafmeyer 2012). It can thus be divided into different currents which are historically anchored. Indeed, since the beginnings of French urban sociology in the 1950s, two approaches have been intertwined: one is an analytical critique of urban projects, while the other attempts to shed light on functioning of urban objects in order to integrate them as effectively as possible into urban projects ${ }^{6}$. These two approaches are often combined rather than opposed, as is the case with the Mission de Recherche Urbaine (1971-1984), which represents in a way the "two sides of the critical posture of urban research in the first half of the 1970s"(Aubertel 2015: 19).

\section{Between Critical Research and Exploration of New Urban Practices: The Successive Positions Taken by Post-War Urban Sociology}

In France, the beginning of urban sociology emerged in the 1950s in the context of the development of post-war urban planning. Among the first works of applied urban sociology are those of Chombart de Lauwe, one of the first researchers to work on new articulations between space and society, although the posterity of his work has been limited (Le Breton, 2015).

In terms of urban projects, the 1960s were clearly marked by the need for housing and the construction of large housing estates, as well as the urban renewal of old centres. State urban planning was strictly regulatory. It was the legal norms that dictated these construction and renovation projects and, not surprisingly, left little room for the participation of residents. 
In response, urban sociology research focused on urban planning, considered by some sociologists as being "a means of social control of the urban order" (Ledrut 1972, quoted by Topalov, 2013), as having a "hegemonic discourse" (Amiot 1986) or quite simply as "the essential heritage of urban sociology" (Castells 1969). Urban sociology was thus mainly concerned with criticism of urban planning (Le Breton 2009) and its directive approaches. One of the most significant works in this respect is the famous Droit $\grave{a}$ la ville, published in 1968 by Henri Lefebvre.

The early 1970s were marked by the launch of major calls for tenders focusing on the social sciences and the emergence of institutions bringing together researchers and practitioners to develop so-called "incentive" research, such as the Plan Construction, which in 1998 became the PUCA (Plan Urbanisme Construction Architecture). Research interests were gradually shifting from the city's production to its uses (Joseph and Grafmeyer 2009). The city was dealt with as such less, but was broken down into a multitude of social or thematic objects: housing, transport, lifestyles, urban spaces, urban culture... by studying in particular the practices, needs and expectations of the inhabitants. Demand thus changed the scale, from macrosocial to microsocial.

\section{The Years 1980-1990: Population Participation and Social Planning}

Interest in the inhabitants also opened the way to the question of their participation in urban projects. Sociologists started to be asked to set up and operate participation or concertation (dialogue) structures, which became a major concern in urban projects in the late 1970s. Participation is understood here in the sense of "public action", i.e. an injunction to implement projects decided by elected and public authorities, or as "mobilisation" (in the idea of co-production) and is distinguished from "participation as collective action" (spontaneous collective action, which can be observed in particular in the context of urban struggles) (Bresson 2014:1). Some legal texts, such as the circular establishing the Plan HVS ("Habitat et Vie Sociale" - Housing and Social Life") for the rehabilitation of large housing estates, made concertation with the inhabitants a condition for the success of these projects (Blanc 1988). The Dubedout report, published in 1983, marks a step forward in the approach of involving residents and making them actors of change.

While the first legal references to "concertation"7 date back to the 1960s (Hélin 2001), or the 1970s in the specific context of living environments (Blanc 1988), it was the 1980s that saw the emergence of most legal frameworks relating to the taking into account or participation of citizens. It was not until Act No. 85-729 of July 1985, on the definition and implementation of planning principles, that the obligation to involve citizens in planning decision-making processes appeared, marking a clear break with public inquiry, the only way of involving the public that had existed until then (Hélin 2001). Concertation became a process of accompanying the development project and differed from public inquiry, which was a single event during the project. However, the texts were not very detailed on the concertation process, the modalities of citizen participation, and thus left a great deal of leeway for local authorities to interpret this procedure (interview with an agent in charge of concertation projects in a local authority, June 2017). This period was therefore characterised by a "textual effervescence (...) on the front of public participation in development decisions" (Hélin, 2001: 96), or by the "implementation of a matrix of involvement of residents" (Abdelhafid Hammouche, Professor of Sociology at CLERSE, personal communication, May 2017).

\section{The ANRU, A Catalyst of the Development of Social Studies in the 2000s}

A few years later, in 2004, the ANRU (National Urban Renewal Agency) was created under the impetus of Jean-Louis Borloo, who was "convinced that it was necessary to 'hit quickly and hard' to get many neighbourhoods out of the spiral of degradation in which they were engaged" (Allen 2014: 36). ANRU thus financed several dozen urban renewal projects over the decade from 2004 to 2014. At the end of this first phase, the evaluation reports were generally positive on urban projects, but less on the reduction of territorial inequalities and the improvement of the living conditions of the inhabitants, which do not strictly depend on the improvement of the building: "In either case, the planning practice is based on the idea - which is as old as urban planning - that intervention on the built environment could 
transform individuals and society (...). For, despite the use of colossal resources for urban renewal and the visible transformations it has produced, the results are not there. Urban renewal operations have had only a limited effect in terms of functional mix and have not succeeded in restoring the desired social mix" (Epstein2012: 5-8).

This opposition between the "urban" and the "human", the main explanation for the fact that urban renewal projects only seem to promote the "living environment" and not the "living conditions" (Allen, 2014), largely contributed to the fact that the second wave of financing of urban projects launched in 2015 required sociological or social functioning studies to be carried out in the territories concerned, in connection with studies on urban renewal, or sometimes in total autonomy, as shown by the many tenders issued in recent years on the topic.

\section{THE GRADUAL IMPLEMENTATION OF CO-CONSTRUCTION WITH THE INHABITANTS ON URBAN PROJECTS}

\section{The 2000s: Actual Implementation of Concertation and Participation of Residents?}

The late 1990s and 2000s saw a proliferation of laws and texts on concertation, detailing in particular the application of obligatory concertation (Hélin, 2001), such as the SRU law (Solidarité et Renouvellement Urbain). Most of these laws and texts were initiated by central authorities (Bresson 2014). In other words, these laws and texts encouraging or prescribing concertation were made... without concertation. This is clearly identified as one of the reasons for their lack of effectiveness by some authors: "Urban policy has remained a policy driven and decided 'from above', above all initiated by professionals and local elected officials. Admittedly, it has not been without concrete effects in terms of urban development or the strengthening of local public services, but it has not produced the expected social dynamics." (Bacquéet Mechmache 2013: 16). This is probably not the only reason for the slow pace of effective implementation of concertation processes. Several actors speak to us on this latency period between the establishment of the institutional and legal framework in the 1980s and their actual application in the 2000s:

"Between the 1980s when these procedures were introduced and the years 2000-2010 when they were actually applied in the field, water went under the bridge, and public information and communication methods had changed slightly." (Interview with an officer in charge of concertation projects in a local authority, June 2017).

"Because from 1980 to 1985, we saw a lot (...) of the great names of architects who started working with the inhabitants. There were many experiences at the time. And then it stopped totally, totally. We didn't care about the people anymore. And then it came back a little bit with the ANRU, but not in masses." (Interview with a project manager within a representative body of the subsidised housing sector, May 2017).

The "institutional injunction" of concertation in the 1980s was understood and appropriated differently according to the actors (Abdelhafid Hammouche, personal communication, May 2017). Why was there such a slow pace in the appropriation and implementation of concertation processes? It may be recalled that the 1980s were also marked by decentralisation, which was characterised by the transfer of responsibilities and decision-making powers from the state to local authorities, which therefore required the "translation" of this "institutional injunction" at the level of each territorial entity.

\section{From Concertation... to Co-Construction?}

The legal framework for the participation of residents in urban projects emerged in the 1980s, but was slow to materialise. We can mention several reasons for this, some of which were mentioned during the interviews conducted: fear, including for local elected officials, of confronting the opinion of their voters, fear of raising expectations or frustration, or of creating a mobilisation that goes against the current of the 
urban project already designed, the need to "control" citizen dynamics or simply the difficulties of implementing regulations that are quite detailed and of adapting them to the size of the project or urban area concerned.

Participatory approaches have been established in many areas of public action since the 1990s-2000s (Bacqué and Gauthier 2011) and multiplied in the 2010s, to the point where many local authorities had to set up dedicated services: "And it has to be said that a real acceleration occurred in 2014, with the renewal of the executives. According to a study conducted by the think tank "Décider ensemble" [Deciding together], 39\% of the services dedicated [to participatory approaches] and which responded to the survey were created on that date. " (Ginibière 2017: 1).

Participation is developing, and with it the vocabulary related to the involvement of citizens in development projects has also diversified: "participation" is a concept that has been used periodically for several centuries (Bresson 2014), "consultation" and "concertation" have been formalised by different regulations... which does not prevent certain confusion between the terms ${ }^{8}$. More recently, we can observe the emergence of a new term, "co-construction". What are the links between concertation and co-construction? One of the actors interviewed answers us for this:

"[Concertation] means involving the inhabitants in the design of the project... but I feel that we are still at the beginning, because in the end these things take very long, I think that we are still very much finding our way. In fact, for me in concertation, there are many possible ambitions, for some people concertation will simply be informing the inhabitants, and for others it will be co-construction, and we try to make it so that concertation is co-construction ${ }^{9}$." (Interview with an urban planner in an architecture and urban planning workshop, May 2017).

Concertation and co-construction are two concepts associated with sociology, or more precisely sociological skills:

"Today there is this demand for co-construction, and co-construction... it is associated with a sociological approach (...). When there is this desire for co-construction that is expressed by the project owner, claiming a career in sociology is reassuring for them, although they do not really know what it is (...)" (Interview with an urban planner in an architecture and urban planning workshop, May 2017).

Thus, the involvement of residents in urban projects requires, in particular, the gradual institutionalisation of concertation and co-construction processes. In the following section, we will see, through some testimonies, what place urban planning actors give to the sociologist in these processes.

\section{UNDERSTANDING THE CURRENT DEMAND FOR URBAN SOCIOLOGY}

We can see the gradual emergence of a new demand for applied sociology, linked to the injunction of participation of inhabitants, or even co-construction. Sociologists, by their skills, are indeed associated with the concertation process, but also with the recognition of knowledge, know-how and civic skills: the use value ${ }^{10}$ and even the use expertise ${ }^{11}$ are increasingly recognised, particularly through the work carried out by sociologists of housing and urban development (Macaire, Fenker, and Biau 2014), which will therefore naturally be used by project owners in the context of urban projects.

As sociology is a complex discipline for many public actors, it is useful to focus on their perception of sociology and what it can contribute to urban projects.

"Socio... for me... what it can bring to urban renewal projects is to make sure (...) that we listen to people... then try to put them in (...) a piece of the city and tell them that they also participate in the atmosphere, in the environment. I think that's the urban sociologist. 
"(Interview with a project manager within a representative body of the subsidised housing sector, May 2017).

"Sociology is still about people... that's how it is perceived in our world" (Interview with an urban planner in an architecture and urban planning workshop, May 2017).

We find a widespread definition among the actors of urban projects: sociology is interested in the inhabitants or users of a district and gives them a voice.

It is on this definition that we have relied, with my collaborators and partners, to respond to different specifications concerning sociological studies prior to the urban renewal project. We have proposed a specific methodology to collect the voice of "invisible" people, whose practices, functioning and expectations are rarely heard; and to make this voice accessible and usable in the context of the urban project. To do this, we drew in particular on various tools of the humanities and social sciences to carry out restoration faithful to the complexity of the data collected, but accessible to the sponsors and actors of the urban project, by working in particular on maps according to actors, making it possible to visualise the uses, representations and mobilities of the inhabitants within their district ${ }^{12}$. This methodology allowed us to mobilise the skills and tools of the social sciences as effectively as possible in order to propose an approach that would meet both the needs of the inhabitants (expressing themselves on the future project) and those of the project owner (ensuring that these needs really are taken into account).

The choice of these project owners to call on sociologists to go beyond the encouragement of ANRU, and shows that taking into account the voice of the inhabitants is now an asset of urban renewal. If sociology makes it possible to "show" this voice, how can it be taken into account in the context of an urban project, which is generally complex and governed by many actors and which extends over several years in duration? In other words, how can we move from a descriptive and comprehensive orientation of sociology to a prescriptive orientation? For urban planning actors, beyond its descriptive function, it is sometimes complex to define how sociology can be concretely useful to urban projects; the discipline is perceived in too abstract a way by actors, who prefer to narrate examples or translate it into skills:

"But for [the project manager], who is ultimately an [architect / urban planner], he doesn't necessarily know how to [perform] activities, whereas a sociologist will know how to do them better." (Interview with an urban planner in an architecture and urban planning workshop, May 2017).

The sociologist therefore does not only perform the function of taking an interest in the inhabitants, or even representing their views on urban projects, he can also become an activity leader, or even a mobiliser: "the sociologist is solicited for his (supposed) ability to solve a particular problem, overcome difficulties, restore collective capacities for cooperation or mobilisation" (Hinaut, Osty, and Servel 2018: 39). Sociology is therefore sometimes drawn on not only for its knowledge, but also for its operational skills, as perceived by urban renewal stakeholders, particularly in terms of leadership and even concertation. This trend is characteristic of new demands for sociology applied to urban projects, and is reflected in the studies in which I have been involved in recent years. Indeed, in several cases, the required sociological studies were completed by a request for support from a concertation body for the rest of the project, thus showing the continuity between the demand for urban sociology and the need for mobilisation expressed by urban renewal stakeholders.

\section{CONCLUSION: TOWARDS A NEW DIALOGUE BETWEEN SOCIOLOGY AND URBAN PLANNING?}

The links between sociology and urban planning are complex and can only be understood through the prism of their successive development studies. If the recent increase in public demand for sociological studies may suggest a renewal of urban research, particularly applied or incentive-based research, a brief 
overview of the major stages in the history of urban sociology shows that it has always been present as a third force between urban public policies and research in urban sociology, the latter having generally positioned itself as a critical approach or even a counterweight to urban policies. Sociology and urban planning have thus regularly rubbed shoulders and confronted each other, participating in the progressive and discontinuous evolution of the history of urban sociology, which "does not present itself as a process of accumulation of knowledge within the framework of a stable institutionalisation, but rather as a discontinuous series of emergences followed by eclipses." (Topalov 2005: 719 quoted by Le Breton, 2009).

Can we speak today of "reconciliation", and the emergence of an applied urban sociology, which is descriptive and comprehensive but also prescriptive and mobilising? The recognition of participation and concertation in urban renewal processes, which sociologists support (Cossart and Talpin 2018) but are also involved in, could certainly be a step in this direction, but it is still superficial or inappropriate in many contexts (Gilli 2018) and therefore does not in itself constitute a real revolution.

Urban incentive research certainly seeks, through its social utility and its capacity to make socio-political problems intelligible, to enlighten operational actors ${ }^{13}$. However, this renewal of dialogue, as we have seen, is notably linked to the current framework of openness to the humanities and social sciences in the implementation of public policies. Thus, as I have tried to demonstrate in this article, it is notably via the ANRU, as well as the demand for participation and concertation of the inhabitants, that the demand for sociological expertise in urban planning has gradually increased.

If sociology is not a predictive science, and still less concerning its own future, we can easily imagine an increased demand for sociology and the humanities and social sciences in the future. This is particularly the case in the area of urban planning, which is increasingly interested in users and therefore naturally and increasingly calls upon sociology (Charbonneau 2017). Sociology could further hybridise with urban planning, as shown by the increase in the profession of "sociologist urban planner", and the involvement of sociologists in supporting the participation and concertation processes of inhabitants, thus moving from a descriptive and reflective sociology to a prescriptive and mobilising sociology.

On the other hand, the urban question will continue to become more complex in the coming years with the densification of the urban fabric and the changes induced in terms of spatial organisation and planning, particularly in urban centres and large conurbations (interview with an agent in charge of concertation projects in a local authority, June 2017). However, this trend is mainly analysed through examples and experiences related to urban renewal and citizen participation, but, is it also clearly marked in other types of urban projects? Finally, what does this demand reveal to us in applied sociology? Is this development specific to the field of urban studies, or is it found in other sectors of sociology or anthropology in which research and action coexist, and which are also explored in this publication? What does this tell us about the changes in the way we look at the Humanities and Social Sciences? These are some of the avenues that will allow us to continue this first research work.

\section{ACKNOWLEDGEMENT}

Maya Leclercq is a doctor of socio-anthropology, specialising in the sociology of urban policy, energy consumption and mobility. She is affiliated to the CLERSE (a mixed research centre in Lille for study and research in sociology and economy) as an associate researcher, and she founded Sociotopie, a workshop of applied humanities and social sciences, in 2017. She has coordinated several evaluations and studies of social functioning within the framework of ANRU projects for the Hauts-de-France Region, for which she has developed new working methods based on the participation of residents, particularly on the theme of mobility and the functional use of neighbourhoods by their residents. 


\section{ENDNOTES}

1. The term "applied" is often used by default to describe action-oriented research, also referred to as "action research", "involved research" or "incentive research". These terms differ from the term "fundamental research", for which no practical application or use is directly foreseen. In this article, we will use the term applied research or, more precisely, applied sociology, which refers either to sociological work carried out by researchers for operational purposes or to a public order for sociological work placed with researchers or consultants.

2. The CIFRE system (Convention industrielle de formation par la recherche) finances doctoral theses carried out jointly within a company and a research laboratory. In the field of human and social sciences, CIFRE theses in urban research are particularly numerous.

3. The National Urban Renewal Agency, which has been approving and financing renovation projects in the most badly struggling neighbourhoods since 2004 .

4. Bulletin official des annonces des marchés publics; their website displays public tender notices.

5. Among the books on the subject, we can mention those by Amiot (1969), Topalov (2013) or Grafmeyer (2008).

6. We can also speak of "modes of relevance", referring to the constitution of a body of knowledge on the one hand, to practical utility on the other hand (Gaudin 1983), or to the tension between research and action (Milanovic 2000).

7. There are many definitions of "concertation" - we understand it here as an opportunity for dialogue between the different parties, allowing a situation of listening and argumentation (CNDP, Comité National pour Débat Public).

8. "What is quite striking is that we often see the use of one term for another, as if there were a certain vagueness in the definition of these terms and as if the actors were not always clear about the processes involved in these different situations. " (Touzard 2006 p. 69).

9. This notion of a larger scale of public involvement for co-construction (the objective being to achieve a consensual project) than for consultation is also found in the definition given by the CNDP (CNDP, Commission nationale du débat public 2018)

10. "Use value..., in other words the 'quality' - social, cultural, and symbolic - brought to spaces by the accumulation of the practices of those who frequent them." (Foret 2008: 8).

11. 'In participatory rhetoric, the term 'use expertise' is sometimes used: it would mean recognising citizens as 'experts in their daily lives'. The term plays on the original meaning of the word, which comes from Latin." (Sintomer 2008:121)

12. This work was inspired in particular by Catherine Jourdan's work on subjective geography (Jourdan, n. d.) and the zoning method developed by CIRAD. It will be the subject of future publications.

13. The political purpose of French incentive urban research is to enlighten operational actors (architects, urban planners, project managers, etc.) in the context of their professional practices and to produce intelligibility in relation to socio-political problems which, at a given moment, seem crucial. It is therefore through its social utility that it is legitimised by its administering institutions, since it is supposed to meet the needs of various social actors." (Milanovic 2000: 130.) 


\section{REFERENCES}

Akermann, G. (2018). La difficile émergence du marché de la prestation de services sociologiques. Sociologies Pratiques. La sociologie sur commandes? 36(mars), 27-36.

Allen, B. (2014). A quoi sert l'évaluation de la rénovation urbaine? In Regards croisés sur l'évaluation de la rénovation urbaine, 21-76.

Amiot, M. (1986). Contre l'Etat, les sociologues : éléments pour une histoire de la sociologie urbaine en France, 1900-1980. Paris: Editions de l'Ecole des hautes études en sciences sociales.

Aubertel, P. (2015). Le Plan Urbain (1971-1998). Une dynamique pour se saisir des enjeux de la société. Rapport, PUCA.

Bacqué, M-H., \& Gauthier, M. (2011). Participation, urbanisme et études urbaines: Quatre décennies de débats et d'expériences depuis 'A ladder of citizen participation' de S. R. Arnstein. Participations 1(1), 36. https://doi.org/10.3917/parti.001. 0036.

Bacqué, M-H., \& Mechmache, M. (2013). Pour une réforme radicale de la politique de la ville. Ca ne se fera plus sans nous. Citoyenneté et pouvoir d'agir dans les quartiers populaires. Rapport au Ministre délégué chargé de la Ville. Rapport, Le Pouvoir d'Agir.

Blanc, M. (1988). Concertation, Sociologie urbaine, Citoyenneté. Les annales de la recherche urbaine, $38,104-112$.

Bresson, M. (2014). La participation: un concept constamment réinventé. Analyse sociologique des enjeux de son usage et de ses variations. Socio-logos Revue de l'association française de sociologie, 9.

Castells, M. (1969). Théorie et idéologie en sociologie urbaine. Sociologie et sociétés, 1(2), 171.

Charbonneau, J-P. (2017). La concertation, cela ne s'improvise pas: la pratique du métier d'urbaniste selon Jean-Pierre Charbonneau. Magazine du design urbain, 24 janvier 2017.

Commission nationale du débat public (CNDP). (2018). Les outils de la participation. CNDP.

Cossart, P., \& Talpin, J. (2018). Rénovation urbaine : sans participation, échec assuré. Médiacités(blog). Retrieved 25 mai, 2018, from https://www.mediacites.fr/forum/ 2018/05/25/renovation-urbaine-sans-participation-echec-assure/

Epstein, R. (2012). ANRU: mission accomplie? In À quoi sert la rénovation urbaine? Edited by par Jacques Donzelot, 43-97. Presses Universitaires de France. https://doi.org/ 10.3917/puf.donze.2012.01.0051.

Foret, C. (2008). Aménager les espaces publics en intégrant les 'contraintes d'usage': le recours aux enquêtes sociologiques et à la concertation sur les projets (1990-2008). Rapport, Le Centre Ressources Prospectives du Grand Lyon.

Gaudin, J-P. (1983). Quand l'Etat commande la recherche. Le développement de la recherche incitative. Les annales de la recherche urbaine, 20, 75-100.

Gilli, F. (2018). Participation : et si on changeait enfin les règles du jeu? métropolitiques.eu. Retrieved 19 février 2018, from http://www.metropolitiques.eu/Participation-et-si-on-changeait-enfin-lesregles- du-jeu.html.

Ginibière, G. (2017, 26 juillet). Les métiers de la participation poussés par les collectivités. La Gazette des Communes.

Grafmeyer, Y. (2008). Sociologie urbaine. Paris: Armand Colin.

Grafmeyer, Y. (2012). La sociologie urbaine dans le contexte français. SociologieS, Novembre. Retrieved from http://journals.openedition.org/sociologies/4179.

Granier, F., Ould-Ferhat, F., \& Thobois, P. (2018). Ou en est la demande sociale de sociologie aujourd'hui ? Sociologies Pratiques. La sociologie sur commandes? 36 (mars), 1-8.

Hélin, J-C. (2001). VI. La concertation en matière d'aménagement. Simple obligation procédurale ou changement de culture? Annuaire des collectivités locales, 21(1), 95-108.

Hinaut, A-C., Osty, F., \& Servel, L. (2018). Réagir, anticiper, soutenir. ce que le monde du travail attend des sociologues. Sociologies Pratiques. La sociologie sur commandes? 36 (mars), 37-46.

Joseph, I., \& Grafmeyer, Y. (2009). L'Ecole de Chicago. Paris: Flammarion. 
Jourdan, C. (s. d). Geographie subjective. Retrieved from http://geographiesubjective.org/Geographie_subjective/ Presentation.html.

Lassave, P. (1997). Les sociologues et la recherche urbaine dans la France contemporaine. Presses universitaires du Mirail. Toulouse.

Le Breton, E. (2009). la sociologie urbaine des Trente glorieuses contre l'urbanisme. Premiers éléments d'un chantier en cours. ESO Travaux et Documents, Espaces et Sociétés, 28, 7-18.

Le Breton, E. (2014). Paul-Henry Chombart de Lauwe, sociologue urbain, chrétien, intellectuel et expert. Chrétiens et sociétés [En ligne], 21, mis en ligne le 25 février 2015, consulté le 27 juillet 2019.

URL: http://journals.openedition.org/chretienssocietes/3661; DOI : 10.4000/chretienssocietes.3661

Lefebvre, H. (1972). Le Droit à la ville suivi de Espace et politique. Paris, Anthropos.

Ledrut, R. (1972). L'Analyse interdisciplinaire de la croissance urbaine : actes du Colloque national sur "l'analyse interdisciplinaire de la croissance urbaine". Editions du CNRS. Paris.

Macaire, E., Fenker, M., \& Biau, V. (2014). Les professionnels face aux exigences participatives. Revue urbanisme. Dossier "Participation ou empowerment?" 392 (printemps), 36-38.

Milanovic, F. (2000). Recherches sur les villes. La 'demande sociale en question'. Sciences de la Société, 49, 129-147.

Piriou, O. (2008). Le nouveau tournant de la sociologie en France dans les années 2000. Sociologies Pratiques, 1(16), 123.

Probetich, J. (2010). La Sociologie urbaine en France: constitution et évolution d'un domaine de recherche spécialisé. Thèse de doctorat en sociologie, Paris: université de Paris 5-Descartes.

Sintomer, Y. (2008). Du savoir d'usage au métier de citoyen? Raisons politiques, 3(31), 115-133.

Topalov, C. (2005). Urbaine (sociologie). In Dictionnaire de la pensée sociologique, PUF, 719-723. Paris: Quadrige.

Topalov, C. (2013). Trente ans de sociologie urbaine - Métropolitiques.

Touzard, H. (2006). Consultation, concertation, négociation: Une courte note théorique. Négociations, $5(1), 67$. 